\title{
IDENTIFIKASI PENYEBAB KEJADIAN LUAR BIASA PENYAKIT GUGUR DAUN KARET DI INDONESIA
}

\author{
Identification of Causes of Rubber Leaves Outbreak In Indonesia \\ Tri Rapani FEBBIYANTI ${ }^{1 *}$, dan Zaida FAIRUZA ${ }^{2}$ \\ ${ }^{1}$ Pusat Penelitian Karet \\ Jalan Raya Palembang - Betung KM 29 Sembawa Banyuasin Sumatera Selatan \\ *Email: trifebbi@yahoo.com \\ ${ }^{2}$ Balai Penelitian Sungei Putih, Pusat Penelitian Karet \\ Galang, Deli Serdang, Po. Box 1415 Medan 2001, Sumatera Utara \\ Diterima : 10 Maret 2020 / Disetujui : 13 April 2020
}

\begin{abstract}
Abstrack
Rubber is an important commodity and a source of farmers' income for Indonesia. One of the causes of low rubber production in Indonesia is due to various diseases. In present, day one of the oubreak rubber diseases in Indonesia is leaffall disease. This study aim to determine the condition of leaf fall disease which was currently an oubreak in Indonesia, isolate and characterize the pathogens that caused it. The observations in the field showed defoliation continuous up to 75-90\%, the canopy became thinner and production dropped to 25-45\% (Data from Sembawa Research Center in May-2018), Methodology scoring of disease intensity by category from International Rubber Research and Development Board (IRRDB). This disease attacked all clones and all plant stages in nurseries, garden plants, immature plants and mature plants. Based on the morphologically analysis it can be seen that this pathogen was Pestalotiopsis $s p$ and obtained 2 symptoms from the Koch Postulate.
\end{abstract}

Keywords: Hevea; leaf fall disease; pathogens; Pestalotiopsis $s p$

\footnotetext{
Abstrak

Karet merupakan komoditas yang penting dan sumber pendapatan petani bagi Indonesia. Salah satu penyebab rendahnya produksi karet di Indonesia karena adanya gangguan berbagai penyakit. Akhir-akhir ini, salah satu penyakit karet yang menjadi outbreak di pertanaman karet Indonesia
}

yaitu penyakit gugur daun. Penelitian ini bertujuan untuk mengetahui kondisi penyakit gugur daun yang saat ini outbreak di Indonesia, mengisolasi serta mengkarakterisasi patogen penyebabnya. Hasil pengamatan di lapangan menujukkan gejala penyakit mengakibatkan pengguguran daun secara terus menerus hingga $75-90 \%$, kanopi menjadi tipis dan produksi turun hingga 25-45\% (Data Balai Penelitian Sembawa Bulan Mei-Juni 2018), Pengukuran intensitas penyakit berdasarkan kategori dari International Rubber Research and Development Board (IRRDB). Penyakit ini menyerang semua klon dan semua stadia tanaman baik di pembibitan, kebun entres, tanaman belum menghasilkan dan tanaman menghasilkan. Berdasarkan hasil secara morfologi terlihat bahwa patogen ini adalah Pestalotiopsis sp dan diperoleh 2 gejala hasil Postulat Koch.

Kata kunci : Gugur daun; Hevea; karet; patogen; Pestalotiopsis sp

\section{PENDAHULUAN}

Penyakit tanaman dapat menimbulkan hambatan pada pertumbuhan dan kerusakan bagian tanaman. Selain itu, penyakit tanaman dapat menurunkan hasil secara langsung atau kematian tanaman secara tidak langsung. Penyakit tanaman karet tersebar di perkebunan karet Indonesia dan menimbulkan kerusakan yang berbeda menurut lokasi dan waktu yang berbeda (Soepadmo, 1980). Ledakan penyakit daun akan terjadi karena pada periode 
pembentukan daun muda yang merupakan kondisi kritis bagi patogen yang terjadi hujan terus menerus sehingga tingginya kelembaban atau kebasahan daun yang sangat sesuai bagi perkembangan penyakit.

Akhir-akhir ini, salah satu penyakit daun yang keberadaannya mulai meningkat di beberapa pertanaman karet yaitu penyakit gugur daun. Observasi awal di lapangan dari penyakit ini ditandai dengan terbentuknya gejala bercak yang terus melebar sehingga jaringan disekitar bercak mengalami nekrosis. Tulang daun dan helaian daun menguning yang terjadi secara sporadis dan kemudian daun menjadi gugur (Malik, 2018). Infeksi berat dapat menyebabkan gugurnya daun berlanjut sampai tajuk tanaman gundul. Penyakit dengan gejala serupa pernah dilaporkan terjadi di Malaysia, di wilayah Labis, Kulai dan Kluang Jahor (Malik et al., 2019)

Penyakit gugur daun ini merupakan penyakit tular udara yang penyebarannya sangat cepat dan mengakibatkan pengguguran daun secara terus menerus. Berdasarkan hasil kuesioner secara daring dan pengamatan langsung, penyakit telah menyebar kebeberapa wilayah di Indonesia yaitu Sumatera bagian Utara, Sumatera bagian Selatan, Jawa Tengah, Jawa Timur dan Sulawesi Tengah, dengan keparahan penyakit yang berbeda (Febbiyanti, 2019)

Pengetahuan mengenai patogen penyebab penyakit penting, terutama untuk penyakit-penyakit baru. Penyusunan strategi pengendalian yang berkelanjutan biasanya harus didasarkan pada sifat patogen bersangkutan. Pada kenyataannya sampai saat ini memang belum ada metode pengendalian yang dapat dibakukan untuk menghambat perkembangan dan penyebaran patogen penyakit gugur daun baru ini. Atas dasar itu pula diagnosis penyakit gugur daun pada tanaman karet perlu dikerjakan agar bisa dijadikan dasar dalam upaya pengendalian penyakit. Penelitian ini bertujuan untuk mengisolasi dan mengkarakterisasi patogen gugur daun baru pada tanaman karet.

\section{BAHAN DAN METODE}

Penelitian dilakukan di Laboratorium Proteksi dan Kebun Percobaan Balai Penelitian Sembawa, Pusat Penelitian Karet, Sumatera Selatan. Kegiatan penelitian berlangsung mulai Oktober 2017 sampai Juni 2019.

\section{Pengamatan Lapangan secara Langsung dan Pengambilan Sampel Tanaman Sakit}

Pengamatan lapangan dilakukan di Kebun Percobaan Balai Penelitian Sembawa. Berbagai jenis gejala yang berkaitan dengan penyakit gugur daun seperti bercak kecil pada daun, nekrosis pada tulang daun, klorosis pada daun diamati dan dikumpulkan sampelnya untuk isolasi. Sampel tanaman sakit dikoleksi dari kebun Percobaan Balai Penelitian Sembawa yang terserang penyakit gugur daun yaitu pada tanaman karet klon BPM 24, BPM 1, PB 260, RRIC 100, PB 330, IRR 112, GT 1, IRR 118, IRR 100, PR 261, BPM 109, dan PB 340. Sampel tanaman yang diambil dari masingmasing klon sebanyak 10 helai daun/klon tanaman.

\section{Isolasi Cendawan Patogen Penyebab Gugur Daun}

Metode isolasi merupakan modifikasi metode isolasi patogen tanaman Mehrota dan Aggarwal (2003). Bagian daun yang bergejala penyakit dari lapangan dibersihkan dengan air mengalir untuk menghilangkan kotoran atau tanah yang menempel, kemudian bagian tanaman tersebut dipotong dengan ukuran 1-3 cm di antara bagian yang menunjukkan gejala dan bagian jaringan yang masih sehat. Potongan jaringan tersebut kemudian didisinfeksi dengan cara merendam di dalam larutan kloroks 3\% selama 3 menit kemudian dibilas dengan air steril. Setelah dikeringkan anginkan di dalam laminar air flow, jaringan tanaman tersebut dipotong kembali menjadi beberapa bagian dengan ukuran $0,5 \mathrm{~cm}$, kemudian ditanam pada medium Potato Dextrose Agar (PDA) dan diinkubasikan pada suhu kamar selama 7 hari. Setiap jenis cendawan yang tumbuh pada media PDA tadi selanjutnya dimurnikan pada medium yang sama untuk digunakan dalam tahapan inokulasi. 


\section{Karakterisasi Patogen secara Morfologi}

Identifikasi penyebab penyakit dilakukan dengan mengamati secara langsung karakter morfologi yang muncul dari contoh bagian tanaman sakit dari lapang maupun hasil isolasi, dan hasil inokulasi. Identifikasi dilakukan berdasarkan koloni (laju pertumbuhan, bentuk, warna) dan morfologi cendawan (hifa, piknidia, konidia). Identifikasi dilakukan dengan menggunakan kunci identifikasi menurut Barnett dan Hunter (1999) untuk identifikasi sampai genus dan untuk identifikasi sampai spesies. Konfirmasi cendawan penyebab juga dilakukan dengan membandingkan pada penelitian sebelumnya menurut Ngobisa et al. (2017) dan Malik. (2018). Buku acuan yang digunakan untuk identifikasi morfologi yaitu :

- Systematics and Species Delimination in Pestalotia and Pestalotiopsis S.L (Amphisphaerial- es, Ascomycota) karya Judith, V.C. dan Hertz, D yang dipublikasikan pada tahun 2016.

- Pestalotiopsis revisited. oleh Maharachchikumbara, S.S.N., Hyde, K.D., Groenewald, J., dan Xudan-Crous, P.W., yang dipublikasikan pada tahun 2014.

- Phylogenetic relationships of Pestalotiopsis and allied genera inferred from ribosomal DNA sequences and morphological characters. Jeewon, R., Liew, E.C.Y., dan Hydea, K.D. yang dipublikasikan pada tahun 2001.

\section{Identifikasi Molekuler dengan Polymerase Chain Reaction (PCR)}

Prosedur ekstraksi DNA menggunakan prosedur ekstraksi yang dikembangkan oleh Doyle dan Doyle (1990) berbasis Cetyl Trimethylammonium Bromide (CTAB). Sampel cendawan ditimbang sebanyak $0.5-0.7 \mathrm{~g}$, lalu diletakkan dalam cawan porselein steril dan ditambahkan 400 $\mu l$ bufer ekstraksi CTAB kemudian digerus dengan mortar steril sampai daun lumat. Sampel yang telah lumat dimasukkan ke dalam tabung eppendorf $2 \mathrm{ml}$, kemudian ditambahkan kembali bufer ekstraksi CTAB sebanyak $400 \mu \mathrm{l}$ dan dikocok dengan pusaran (vortex) selama 2-3 menit.
Tahapan selanjutnya dilakukan inkubasi sampel dalam water bath bersuhu $65{ }^{\circ} \mathrm{C}$ selama 15 menit sambil tabung dibolak-balik setiap 5 menit. Tahapan ini dilakukan untuk mengoptimalkan kerja bufer ekstrak yang ditambahkan ke dalam sampel. Sampel kemudian dikocok selama 2-3 menit, selanjutnya dilakukan sentrifugasi sampel dengan kecepatan $12000 \mathrm{rpm}$ selama 10 menit pada suhu $25^{\circ} \mathrm{C}$.

Supernatan yang telah diperoleh kemudian diambil dan ditambahkan dengan larutan chloroform: isolamylalkohol atau chisam dengan perbandingan 24:1. Penambahan chisam ini dilakukan untuk mengekstraksi DNA dari kontaminan. Suspensi kemudian dikocok sampai rata untuk optimalisasi homogenasi. Selanjutnya suspensi disentrifugasi pada kecepatan $12000 \mathrm{rpm}$ pada suhu $25{ }^{\circ} \mathrm{C}$ selama 10 menit, sehingga diperoleh suspensi dengan tiga lapisan; lapisan atas berwarna hijau jernih, lapisan tengah berwarna hijau keruh, dan lapisan bawah berupa pelet yang berwarna hijau tua. Supernatan pada lapisan paling atas diambil dan ditambahkan dengan $2 / 3 \times$ volume larutan isopropanol dingin untuk presipitasi DNA. Supernatan yang telah ditambahkan isopropanol kemudian digoyang perlahanlahan dengan cara membolak-balikkan tabung. Untuk mengendapkan DNA (pelet DNA), larutan disentrifugasi kembali pada kecepatan $12000 \mathrm{rpm}$ pada suhu $4^{\circ} \mathrm{C}$ selama 20 menit.

Endapan DNA dicuci dua kali dengan $70 \%$ etanol sebanyak $500 \mu 1$, disentrifugasi selama 5 menit pada kecepatan $12000 \mathrm{rpm}$ dengan suhu $4{ }^{\circ} \mathrm{C}$, kemudian cairan etanol dibuang dan pelet DNA dikeringanginkan, lalu dilarutkan dalam $50 \mu \mathrm{L}$ bufer TE $(10 \mathrm{mM}$ Tris-HCl, 1 mM EDTA, pH 7,5) dan ditambahkan $1 \mu \mathrm{L}$ RNAse A (10 mg/ mL) kemudian diinkubasi pada suhu $37{ }^{\circ} \mathrm{C}$ selama 30 menit sampai 1 jam.

Amplifikasi dilakukan menggunakan PCR pada volume total $25 \mathrm{ml}$ dalam siklus termal sebagai berikut : 1 Siklus pada $94^{\circ} \mathrm{C}, 3$ menit, 35 Siklus untuk: Denaturasi : $94^{\circ} \mathrm{C}$, 1 menit, Annealing : $60^{\circ} \mathrm{C}, 1$ menit, Extention: $72^{\circ} \mathrm{C}, 2$ menit. 1 Siklus : Final extention: $72^{\circ} \mathrm{C}$, 10 menit, Holding temperature : $4^{\circ} \mathrm{C}, \sim$ Hasil 
PCR divisualisasi pada gel agarosa $1 \%$ atau $2 \%$ dalam larutan buffer TAE $1 \times(40 \mathrm{mM}$ Tris, $20 \mathrm{mM}$ asam asetat, dan $1 \mathrm{mM}$ EDTA) pada 80 Volt selama 45 menit dalam suhu ruang. Pembuatan agar rose mengikuti rumus $1 \% \mathrm{x}$ kapasitas cetakan gel agaros (ml). Untuk mempermudah visualisasi, gel diberikan pewarnaan dengan cara merendam dalam etidium bromide ( \pm 30 menit hingga 1 jam ), dan pita divisualisasikan di bawah sinar UV dan difoto menggunakan sistem dokumentasi gel (gel doc). Ukuran fragmen DNA yang diperkuat ditentukan menggunakan penanda berat molekul (GeneRuler $100 \mathrm{bp}$ DNA Ladder dan $1 \mathrm{~kb}$ DNA ladder marker (Fermentas, USA)).

Sekuensing dari hasil produk PCR dilakukan ke pihak ketiga (First Base di Kuala Lumpur, Malaysia ). Hasil sekuensing produk PCR berupa ikatan basa ITS1-ITS4 yang selanjutnya dibaca serta di edit dan diurutkan dengan menggunakan program MEGA versi 7.0 (Tamura et al., 2007). Hasil edit urutan basa ITS1-ITS4 tersebut kemudian dibadingkan dengan urutan basa ITS1-ITS4 jenis lainnya yang tersedia di GenBank menggunakan layanan jaringan Basic Local Alignment Search Tool (BLAST) dari Pusat data dan informasi Bioteknologi Nasional (NCBI). Hasil pembandingan urutan basa menghasilkan nama jenis organisme tertentu yang memiliki hubungan berdekatan dengan urutan basa ITS1-ITS4 yang diperoleh, dengan nilai penting antara 98\% hingga 99\%.

\section{Postulat Koch}

Tanaman yang digunakan untuk Postulat Koch yaitu bibit karet yang ditanam di dalam pot plastik (polybag). Inokulasi dilakukan pada bagian daun dari bibit polybag tersebut yang masih berwarna coklat sampai hijau. Inokulasi dilakukan dengan cara pengolesan spora pada bagian bawah daun. Pengamatan gejala penyakit dilakukan setiap hari mulai hari pertama setelah inokulasi sampai muncul gejala Untuk memastikan munculnya gejala pada tanaman hasil inokulasi disebabkan oleh isolat cendawan yang sama maka dilakukan tahapan reisolasi. Reisolasi dilakukan dengan menggunakan metode yang sama seperti pada percobaan isolasi di atas.

\section{HASIL DAN PEMBAHASAN}

\section{Pengamatan Gejala Penyakit di Lapangan dan Pengambilan Tanaman Sakit}

Penyakit ini ditandai dengan terbentuknya gejala bercak yang terus melebar yang berukuran 1-2 cm, kemudian jaringan di sekitar bercak mengalami nekrosis. Tulang daun dan helaian daun menguning yang terjadi secara sporadis dan kemudian daun menjadi gugur. Infeksi berat dapat menyebabkan gugurnya daun berlanjut sampai tajuk tanaman gundul (Gambar 1). Gejala pada penyakit ini memang sangat khas yaitu nekrosis yang berbentuk bundar dengan dikelilingi oleh
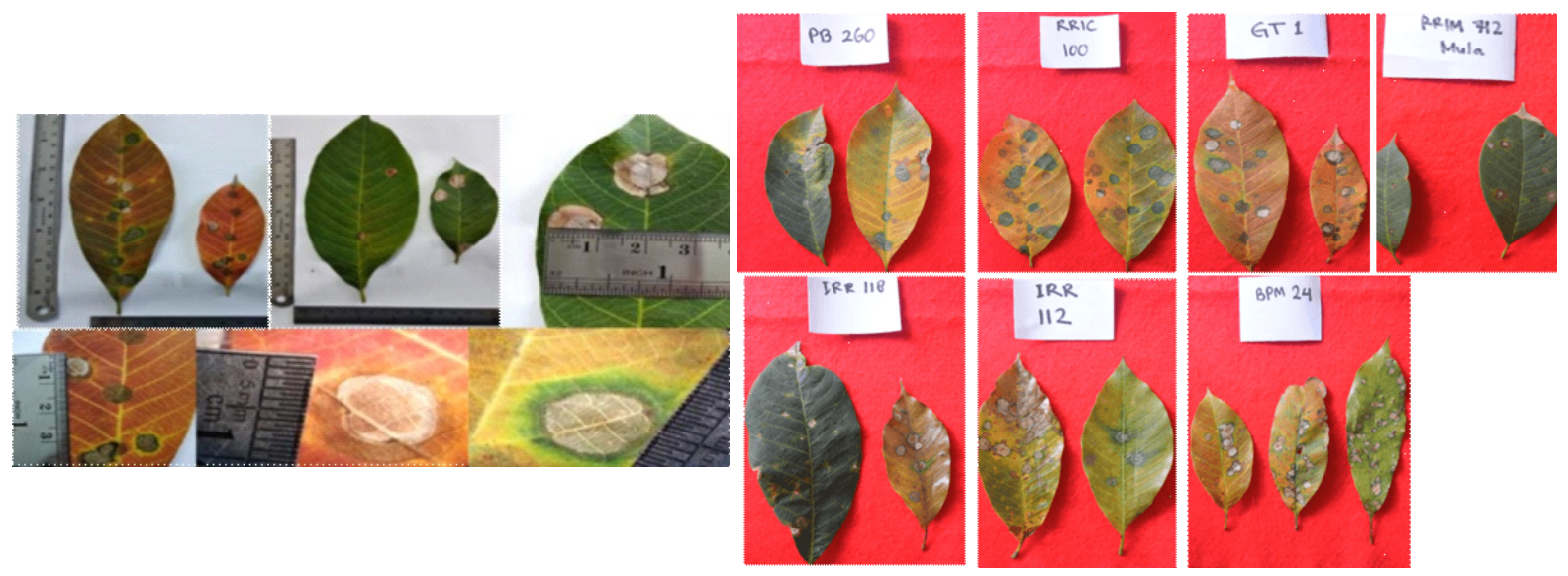

Gambar 1. Gejala penyakit gugur daun

Figure 1. Symptoms of leaf fall disease 
batasan yang tegas. Batasan ini merupakan hasil infeksi lokal dari patogen, dimana pertumbuhan patogen terhalang oleh jaringan pemisah. Menurut Agrios (2005) bercak daun (leaf spot) adalah bercak nekrosa yang mempunyai batasan tegas yang disebabkan karena pertumbuhan jamur terhalang oleh jaringan pemisah. Jika jaringan yang sakit ini gugur maka dinamakan shot holes yang tembus peluru. Daun terkadang berubah warna seketika menjadi kuning orange disemua helain daun Menurut Malik (2018) gejala berupa bintikbintik akan mulai sebagai bintik-bintik kuning, coklat atau hitam yang sangat kecil yang berukuran $1 / 4$ inc, di bawah kondisi lingkungan yang optimal, bintik-bintik dapat membesar dan bertambah jumlahnya sampai bergabung untuk membentuk hawar daun. Seringkali, bintik-bintik berubah warna keabu-abuan yang diuraikan dalam warna hitam.

Penyakit ini menyerang semua klon dan berdasarkan pengamatan tidak terdapat klon yang resisten terhadap penyakit ini (Gambar 2), kemudian penyakit ini juga menyerang semua umur tanaman baik di pembibitan, entres, tanaman belum menghasilkan (TBM) dan tanaman menghasilkan (TM) dengan keparahan penyakit yang bervariasi. Penyakit ini mengakibatkan pengguguran daun secara terus menerus dengan cepat/ serentak yang mengakibatkan kanopi tanaman menjadi tipis, meranggas (defoliation) hingga 75-90\% dan akhirnya tidak terdapat daun di kanopi tanaman (Gambar 3).

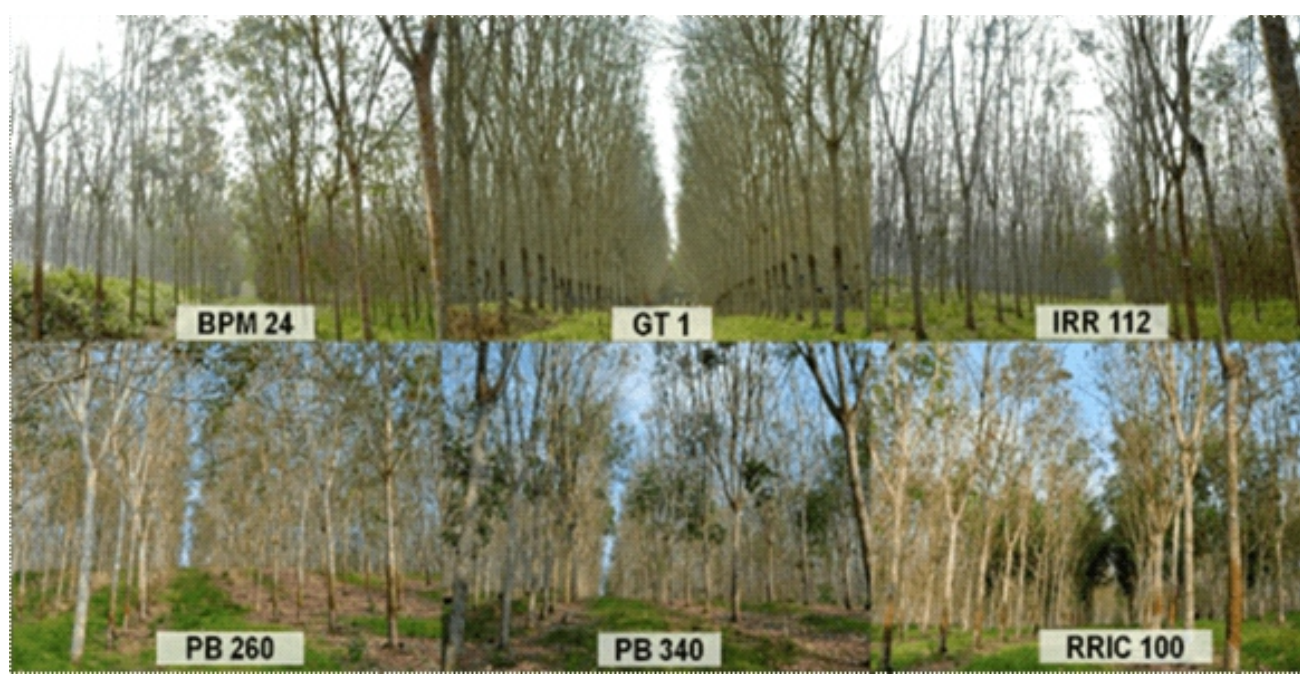

Gambar 2. Penyakit gugur daun baru menyerang semua jenis klon Figure 2. New Leaffall disease attacks all types of clones

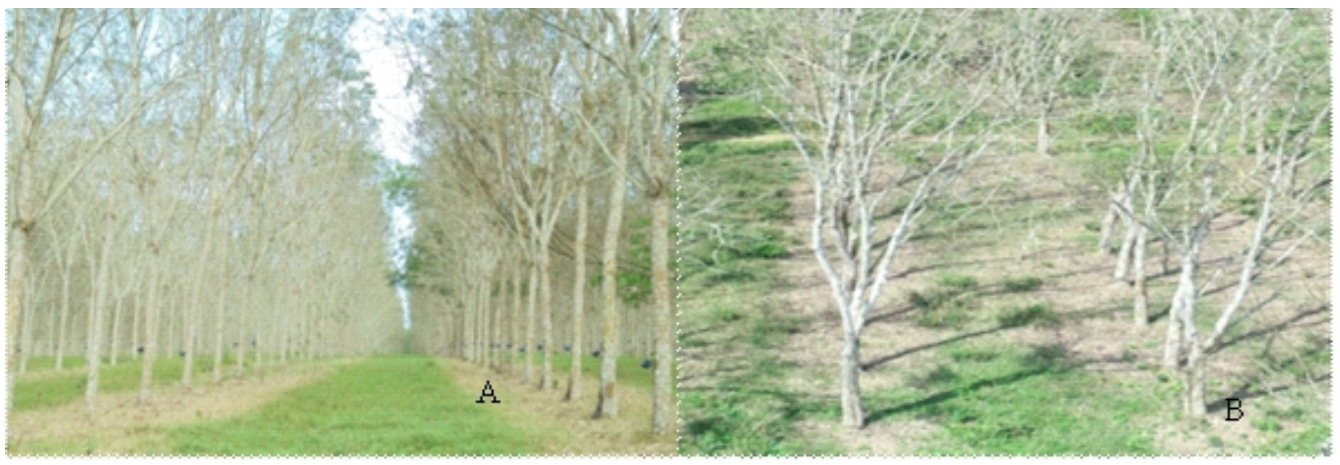

Gambar 3. Kondisi kanopi akibat serangan penyakit daun baru Figure 3. Canopy condition for the impact of new leaffall disease 
Kemudian, pengamatan juga dilaksanakan secara daring dan juga secara langsung, pengamatan dilaksanakan dengan penyebaran angket berisi pertanyaan tentang kejadian penyakit dan faktor-faktor yang berhubungan dengan kejadian penyakit. Berdasarkan hasil terlihat bahwa penyakit telah menyebar kebeberapa wilayah kebun produksi PT. Perkebunan Nusantara di Indonesia yaitu di Sumatera Utara dengan luas serangan 9.500 Ha, Sumatera bagian Selatan dengan luas serangan lebih dari $2.600 \mathrm{Ha}$, Jawa Tengah dan Jawa Timur dengan luas serangan $200 \mathrm{Ha}$ dan Sulawesi Tengah dengan luas serangan $75 \mathrm{Ha}$, dengan keparahan penyakit yang berbeda. Penyakit ini sudah terdeteksi sejak tahun 2016, dan terus berlanjut sampai sekarang (Tabel 1).

Berdasarkan pengamatan di lapangan, gejala lebih banyak dijumpai pada daun yang tua dibandingkan daun muda, dan daun yang gugur juga lebih banyak pada daun tua dibandingkan daun muda. Menurut Malik (2018), penyakit ini lebih banyak menyerang daun yang tua, gejala berupa bercak coklat konsentris yang menonjol dan lebih banyak terdapat pada bagian ujung dan pinggir daun. Hasil survei secara daring juga mengindikasikan bahwa penyakit lebih banyak menyerang daun dalam stadia tua (mature) atau yang berwarna hijau gelap (Gambar 4).

Tabel 1. Luas serangan penyakit gugur daun baru tahun 2018 Table 1. List of area affected by new leaf fall disease

\begin{tabular}{|c|c|c|c|}
\hline $\begin{array}{l}\text { Provinsi } \\
\text { Province }\end{array}$ & $\begin{array}{l}\text { Lokasi } \\
\text { Location }\end{array}$ & $\begin{array}{l}\text { Luas terserang } \\
\text { Areal attacked } \\
(\mathrm{Ha})\end{array}$ & $\begin{array}{l}\text { Kondisi Tajuk } \\
\text { Condition }\end{array}$ \\
\hline \multirow[t]{3}{*}{ Sumut } & Perusahaan negara & $9.263,34$ & Meranggas $50 \%$ \\
\hline & Perusahaan Swasta & 1500 & Meranggas $50 \%$ \\
\hline & Perusahaan Swasta & $1.388,48$ & Meranggas $50 \%$ \\
\hline \multirow[t]{10}{*}{ Sumsel } & Perusahaan Swasta & 125 & $-100-$ \\
\hline & Perusahaan Swasta & 1982,57 & Meranggas $25-50 \%$ \\
\hline & PTPNVII, Tebenan & 304 & Meranggas $50 \%$ \\
\hline & Balit Sembawa & 1500 & Meranggas $50 \%$ \\
\hline & Perusahaan negar, Musilandas & 347 & Meranggas $50 \%$ \\
\hline & Petani,Prabumulih & 474 & - \\
\hline & Petani, Muratara & 100 & \\
\hline & Kel Tani, Banyuasin & 105 & Meranggas $75 \%$ \\
\hline & Petani, Musirawa & 155 & - \\
\hline & Petani, Bayung Lincir & - & - \\
\hline Lampung & Perusahaan negara, Tulung Buyut & 154 & Meranggas $50 \%$ \\
\hline Bengkulu & Perusahaan negara, Padang Plawi & - & - \\
\hline Jawa Tengah & Perusahaan negara, Kebun Tretes & 30 & Tidak meranggas \\
\hline Jawa Timur & Perusahaan negara, Jatirono & 153,69 & Meranggas 25\% \\
\hline Sulteng & Perusahaan negara, Beteleme & 75 & Meranggas total \\
\hline
\end{tabular}

Sumber (Source) : Febbiyanti et al (2018)

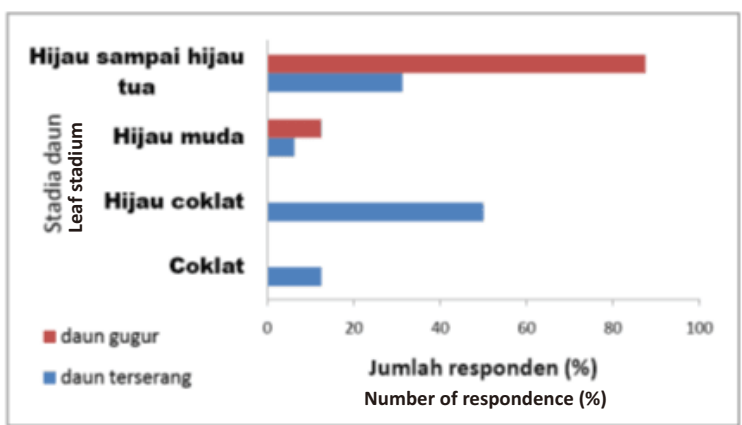

Sumber (Source) : Febbiyanti et al (2018)

Gambar 4. Stadia daun yang terserang dan gugur akibat penyakit gugur daun baru

Figure 4. Stage ofleaves attacked and fall caused new leaffall disease 
Selanjutnya, kehilangan produksi yang terjadi akibat penyakit ini mencapai lebih dari $25 \%$, Berdasarkan data Balai Penelitian Sembawa, penurunan produksi pada bulai Mei 2018 sekitar $27 \%$, bulan Juni turun $45,8 \%$ dibanding tahun 2017 . Pada tanaman karet, produksi puncak biasanya terjadi setelah gugur daun alami setelah masuk musim hujan sekitar bulan Januari Juni, namun hal ini berbeda pada tahun 2018, terjadi penurunan pada bulan-bulan tersebut akibat serangan penyakit ini yang terjadi sejak bulan November 2017 dan terus meranggas sampai awal Juni 2018.

\section{Karakterisasi Patogen secara Morfologi}

Karakter morfologi dari patogen gugur daun ini ini memiliki warna koloni yang berubah-ubah seiring dengan bertambahnya umur biakan. Pertumbuhan miselia tidak cepat, diameter koloni biakan berumur 1 hari yaitu $0,4-0,5 \mathrm{~cm}$ dan pada biakan berumur 11-15 hari, miselia telah memenuhi petri yang berdiameter $9 \mathrm{~cm}$. Kemudian, perubahan warna terjadi dari putih menjadi putih krem (Gambar 6). Koloni memiliki margin yang halus, bahkan bergelombang, tidak berwarna. Miselium udara berwarna putih kapas. Acervuli terbentuk pada miselium udara yang mengandung massa konidia hitam berlendir. Jamur ini memiliki warna koloni di bagian atas koloni berwarna putih yang lama kelamaan akan muncul bintik-bintik hitam dan bagian dasar koloni bewarna kuning kecoklatan.

Miselia bersekat dan tidak memiliki inti. Konidia berbentuk fusiform, bersel lima, lurus atau sedikit melengkung dan kadang-kadang berbentuk setula. Sel-sel terdiri dari tiga sel bagian tengah yang berwarna/berfigmen dan sel hialin dibagian apikal dan bagian basal. Sel apikal agak memanjang atau menyempit ke ujung, sedang sel basal/hialin agak silindrik. Setula hiain dan posisinya agak melengkung, setula tampaknya mudah lepas dari pangkalnya. Pedisel hialin terletak di ujung sel basal (tampak seperti ekor konidia). Semua bagian konidiospora yang hialin yaitu sel apikal, sel basal, dan setula. Semua bagian mudah berubah bentuk dan akan mengkerut apabila disimpan lama .

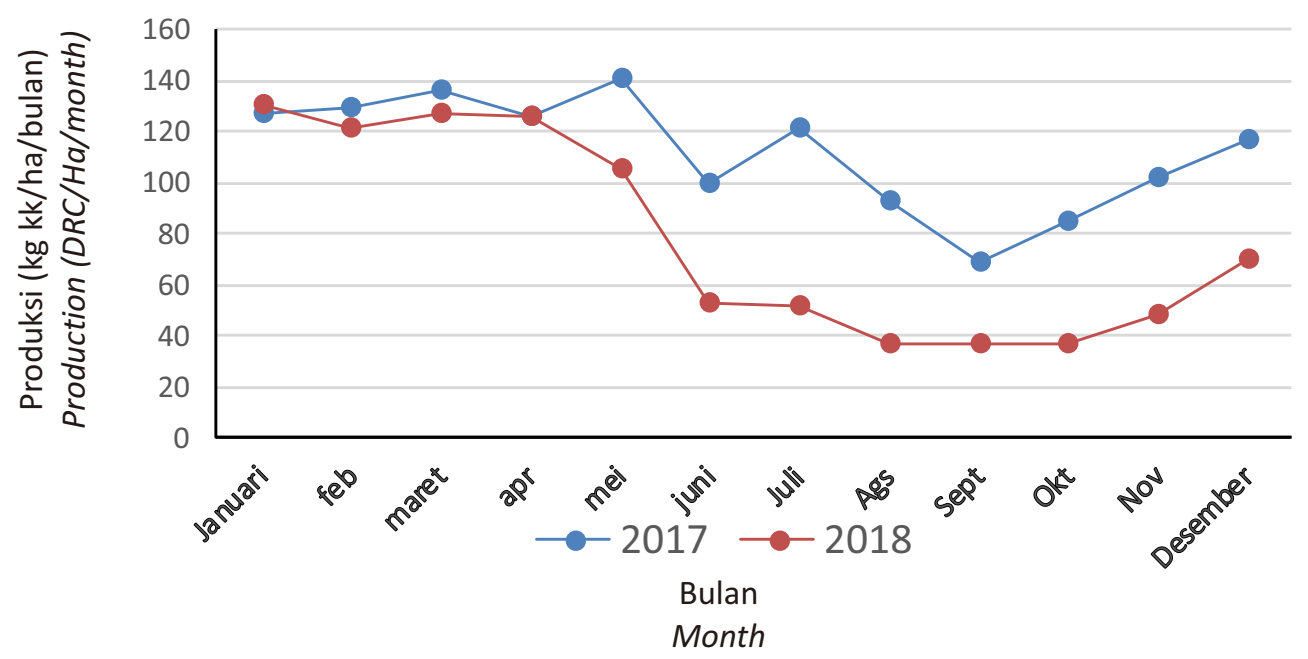

Gambar 5. Data produksi tahun 2017-2018 di Balai Penelitian Sembawa Figure 5. Production in 2017-2018 at the Sembawa Research Center

Pestalotiopsis pada karet memiliki isolat putih pada 5 hari pertama, kemudian berubah menjadi putih krem setelah 8 hari. konidia berbentuk fusoid, ellipsoid lurus hingga sedikit melengkung (20-30 x 6,5 - 8,5 $\mathrm{m})$ dengan empat septa. Dua hingga empat pelengkap apikal hialin (sebagian besar tiga, $15,5-26,5 \mu \mathrm{m}$ ) melekat pada setiap sel hialis apikal sub-silinder, berdinding tipis, dan satu tambahan hialin panjang $3-7 \mu \mathrm{m}$ melekat pada setiap sel basal. Panjangnya bervariasi dari 20,15 $\mu \mathrm{m}$ hingga $30 \mu \mathrm{m}$ dan lebar dari 5,8 $\mu \mathrm{m}$ hingga 9,88 $\mu \mathrm{m}$. Sel dengan apikal pelengkap berkisar 2,7 hingga 6,9 um (Ngobisa et al, 2017). 
Berdasarkan bentuk konidia secara morfologi terlihat bentukan seperti ini dimiliki oleh genus Pestalotiopsis (Maharachchikumbura et al., 2014; Nyaka et al., 2017). Pestalotiopsis telah menyerang komoditas karet sejak 1975 di pembibitan, pada November 2017 dilaporkan terjadi pada kebun petani di Labis, Kulai dan Perkebunan Setindan Kluang Johor Malaysia dan patogen ini menyerang daun, pucuk, ranting, buah dan biji yang terinfeksi, dan patogen ini juga menyerang kelapa sawit (Adam et al., 2019). Pada kelapa sawit, patogen menyebabkan penyakit Pestalotiopsis Leaf Spot Diseases yang sering bersimbiosis dengan jamur lain yaitu $P$. palmarum, P.glandicula, Colletotrichum, Curvularia, Gloesporium dan Helminthosporium (Escalante et al., 2010), dan penyakit ini meningkat dengan bertambahnya keberadaan serangga
Leptopharsa gibbicarina (Mahamooth et al., 2018). Pada manggis genus pestalotia menyebabkan munculnya getah kuning (Suada \& Sunit, 2014).

Patogen ini merupakan parasit lemah yang menginfeksi luka-luka. Spora jamur (konidium) dipencarkan oleh angin. Untuk jarak dekat spora dapat terbawa oleh percikan air dan serangga (Douira et al., 2014). Selanjutnya, Pestalotiopsis sp. juga bersifat endofit pada tanaman tingkat tiggi tinggi (Metz et al. 2000) dan merupakan patogen opportunis dan menyerang beberapa tanaman hias (Pirone, 1978). Spesies Pestalotiopsis juga dilaporkan menyerang beberapa tanaman yang ditanam dalam pot dan jumlah tanaman yang terinfeksi terus meningkat (Hopkins \& McQuilken, 2000).

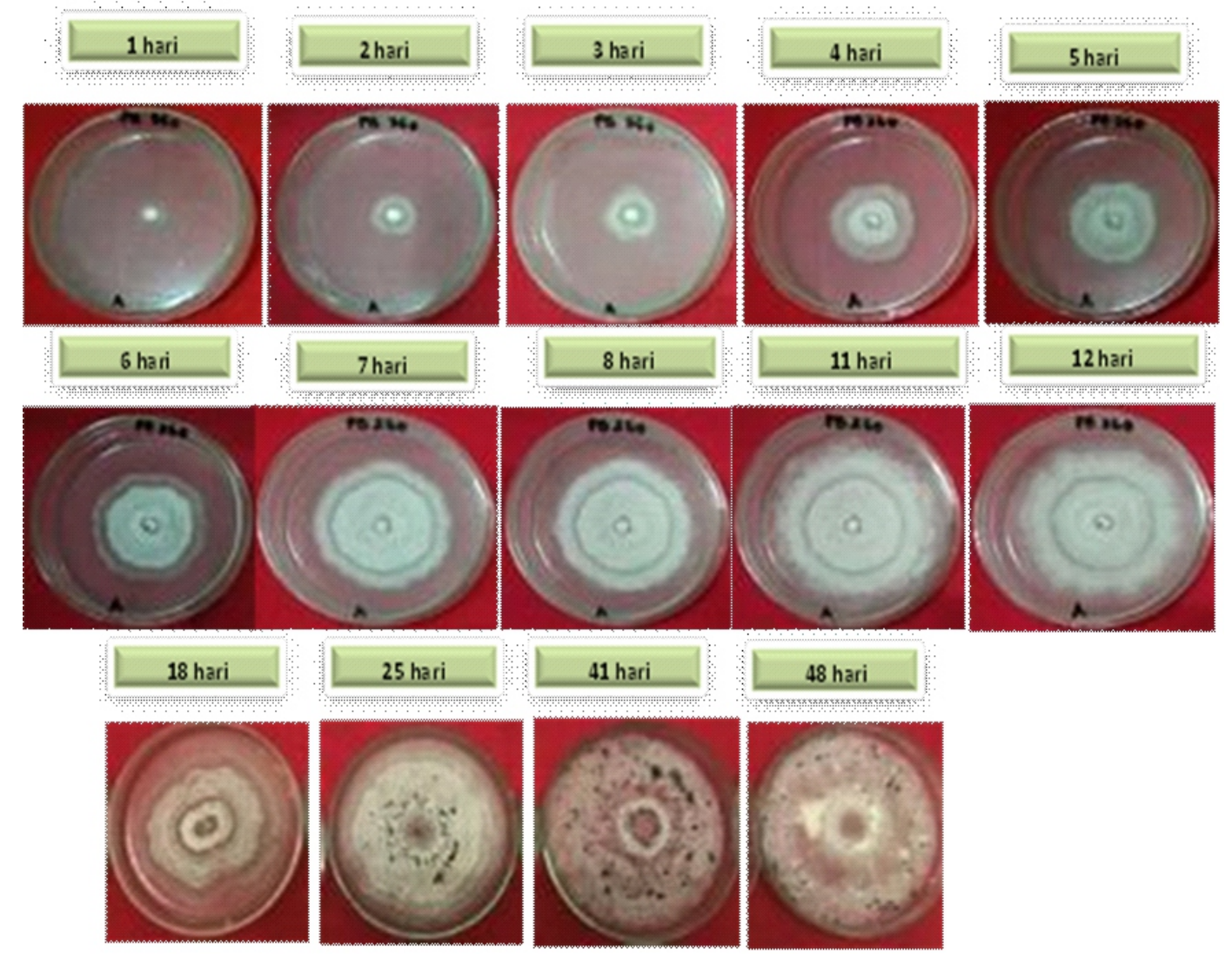

Gambar 6. Koloni patogen penyakit gugur daun baru pada media Potato Dextrosa Agar Figure 6. Colonies of new leaffall diseases on potato dextrosa agar (PDA) media 
Tabel 2. Karakterisasi konidia patogen penyebab penyakit gugur daun karet Table 2. Characterization of the pathogenic conidia caused leaf fall rubber diseases

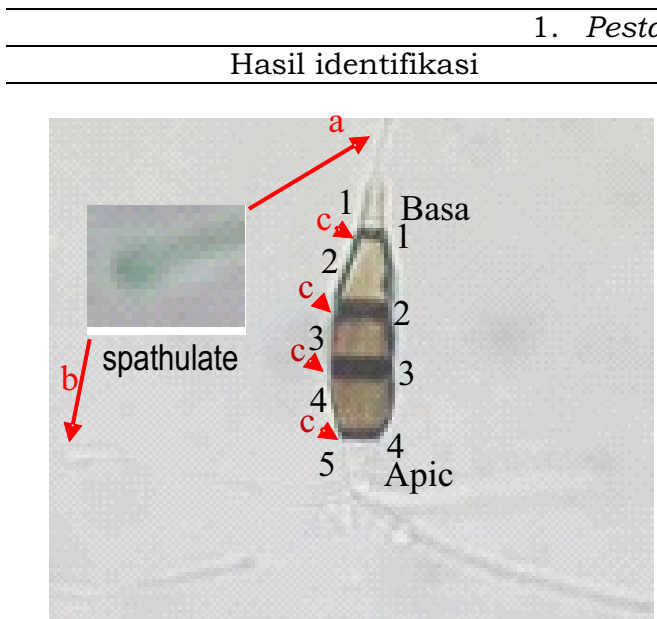

Konidia Pestalotiopsis clavata

Konidia berbentuk lonjong sedikit mengembung atau clavate (apical lebih besar di banding basal) dapat lurus atau melengkung, memiliki 5 sel dengan 4 septa berwarna hitam tebal sempit (c), berwarna kuningan kecoklatan (olive) terang hingga gelap (seragam dengan densitas berbeda), memiliki kenob (spathulate tips) di ujung embel-embel apical (setulae (a)) dan basal (pedicel (b)), berukuran $\pm 23,85 \mu \mathrm{m} \mathrm{x} \pm 7,07$ $\mu \mathrm{m}$.

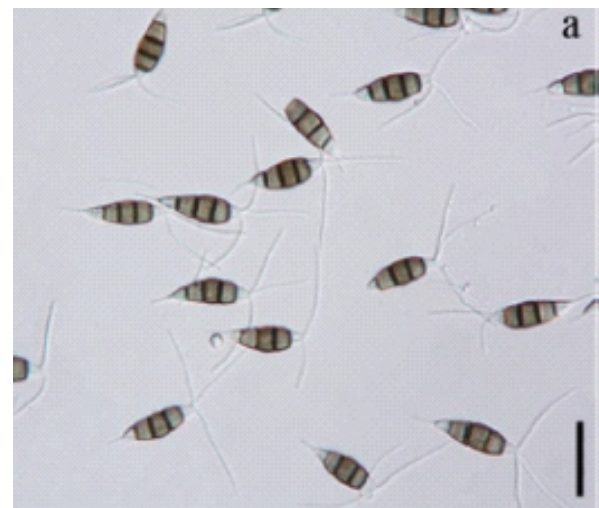

Konidia berukuran 20-27 $\mu \mathrm{m}$ x 6.5-8 $\mu \mathrm{m}$

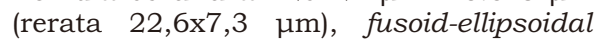
(lonjong) dapat tegak hingga sedikit melengkung, 4 septa. Bagian basal sel memiliki panjang 4-5 $\mu \mathrm{m}$ (rerata 4,6 $\mu \mathrm{m})$, menyerupai tanduk (mengerucut) hingga ujung tumpul, hialin, berdinding tipis, dan verruculosa (berintik).

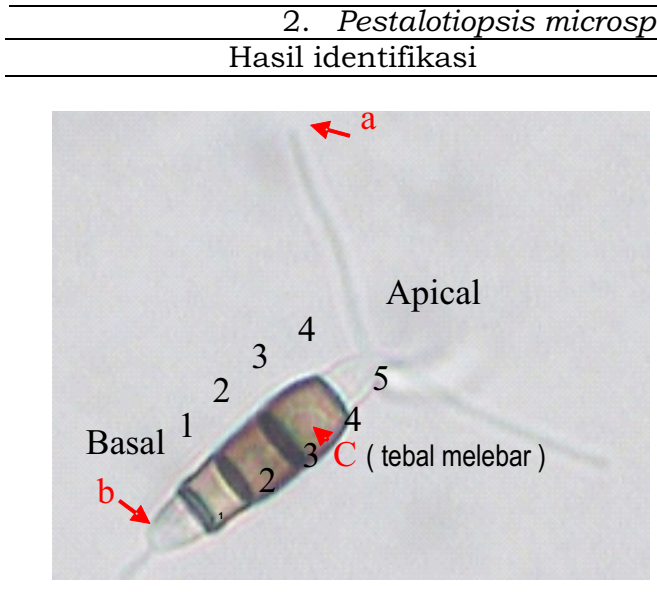

Konidia Pestalotiopsis microspora syn. Pestalosphaeria hansenii. Konidia berbentuk lonjong sedikit mengembung atau clavate (apical lebih besar di banding basal) dapat lurus atau melengkung, memiliki 5 sel dengan 4 septa berwarna hitam tebal sempit (umumnya tebal melebar pada septa ke 3 (c)), berwarna coklat terang hingga gelap (seragam dengan densitas berbeda, umumnya sel ke 3 coklat gelap (d)), tidak memiliki kenob (tanpa spathulate tips) di ujung embel-embel apical (setulae (a)) dan basal (pedicel (b)), berukuran $\pm 20,43-26,29$ $\mu \mathrm{m} x \pm 5,82-8,17 \mu \mathrm{m}$
Literatur

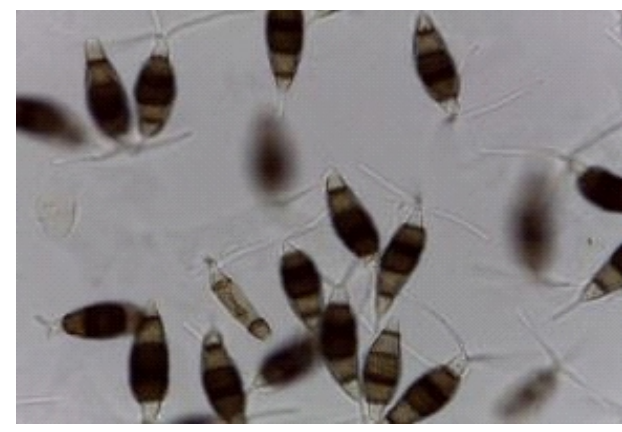

Conidia $P$. microspore berwarna coklat dengan panjang 25,21 ( $\pm 1,3) \mu \mathrm{m}$ dan lebar $5,63( \pm 1,3) \mu \mathrm{m}$. Bagian apical mempunyai 2 3 embel-embel dengan panjang embel-embel bervariasi berkisar $18.04( \pm 1,50) \mu \mathrm{m}$ dan satu embel-embel pada bagian basal dengan panjang $4,06( \pm 1,2) \mu \mathrm{m}$. 


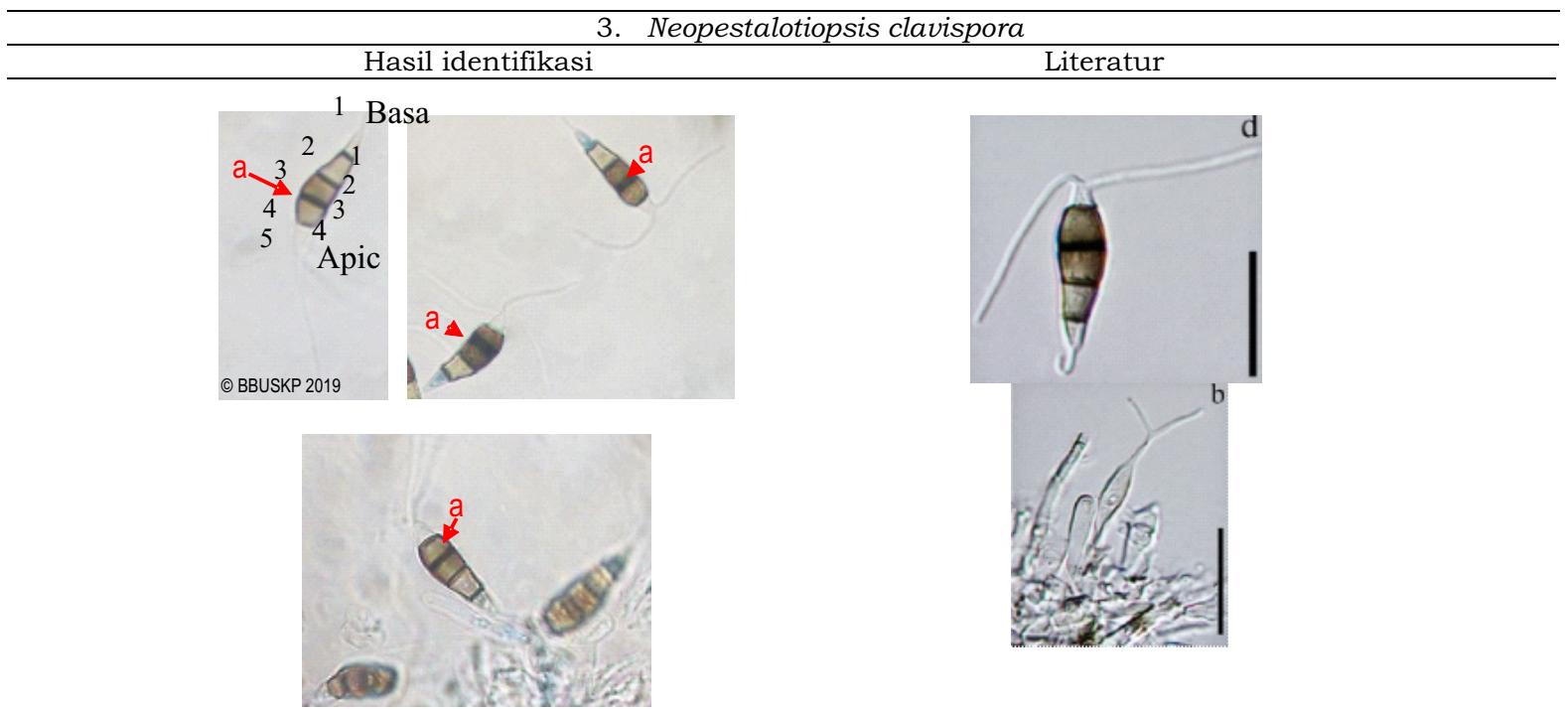

Konidia berbentuk lonjong sedikit mengembung atau clavate (apical lebih besar di banding basal) dapat lurus atau melengkung, terdiri dari 5 sel dengan 4 septa berwarna hitam tebal sempit (kadang tebal melebar, umumnya septa ke 3 (c)), berwarna coklat (berbeda warna dari coklat terang hingga coklat gelap), berintik, tidak memiliki kenob pada ujung embel-embel apical (setulae (a)) dan basal (pedicel (b)) atau tanpa spathulate tips, berukuran $\pm 22,26 \mu \mathrm{m} \times \pm 7,50 \mu \mathrm{m}$.

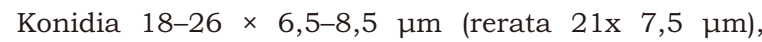
fusiform, 4-septa, lurus atau sedikit melengkung dan clavate-fusiform; sel basal panjang dan mengerucut, hialin, ramping dan verruculose, panjang 4- $5 \mu \mathrm{m}$ (rerata 4,2 $\mu \mathrm{m}$ ); dengan tiga sel dibagian tengah panjang $13,7-15,3 \mu \mathrm{m}$ (rerata $14,7 \mu \mathrm{m})$, coklat gelap hingga olivaceous, dinding pararel dipermukaan meristem lebih gelap (periclinal) dibanding sel sisanya, bermacam warna, verruculose, sel ke dua dari basal colat pucat, 4,3-5,3 $\mathrm{m}$ (rerata 4,8 $\mathrm{m}$ ); sel ke tiga coklat gelap, 5,5-6,4 $\mu \mathrm{m}$ (rerata 5,8 $\mu \mathrm{m}$ ); sel ke empat gelap, 4,5-5,8 $\mu \mathrm{m}$ (rerata $5 \mu \mathrm{m}$ ); sel apical panjang 3,3-4,2 $\mu \mathrm{m}$ (rerata 3,7 $\mu \mathrm{m}$ ), pendek, menggembung memanjang, hialin, subsilendris; dengan embel-embel apical panjang 19-30 $\mu \mathrm{m}$ (rerata 24,5 $\mu \mathrm{m}$ ), tubular, 2-3 (umumnya 2), yang keluar dari ujung apical sel; bagian basal terdapat dengan embel-embel, filiform.

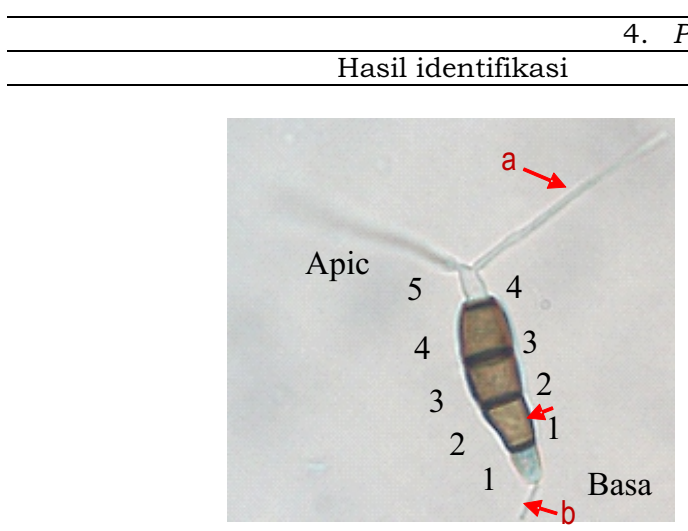

Konidia berbentuk lonjong hingga mengembung dengan kedua ujung sama besar, dapat lurus hingga sedikit melengkung, terdiri dari 5 sel dengan 4 septa berwarna hitam tebal sempit, berwarna coklat muda hingga olive (beraneka warna), ramping, berdinding tipis dan halus, hialin, berintik, tidak memiliki kenob pada ujung embelembel apical (setulae (a)) dan basal (pedicel (b)) atau tanpa spathulate tips, berukuran $\pm 25,71 \mu \mathrm{m} \times \pm 6,43$ $\mu \mathrm{m}$.

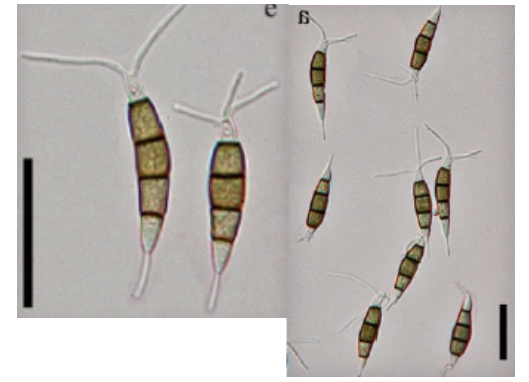

Konidia lonjong, lurus hingga sedikit melengkung, 4

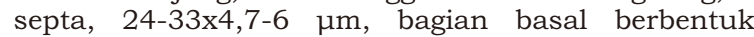
tanduk-membulat, hialin atau sedikit olive, ramping, berintik dengan panjang 3,5-5,5 $\mu$ m dengan tiga sel tengah, dolliform-silinder, dinding tebal sedikit berintik, septa mengerut, berwarna gelap dibanding sel lainnya, ketiganya memiliki panjang $17-21 \mu \mathrm{m}$, sel ke 2 5-6.2 $\mu \mathrm{m}$; sel ke 3 6-7 $\mu \mathrm{m}$; sel ke 4 6-8 $\mu \mathrm{m}$; apical sel hialine, silinder-subsilinder dengan panjang $4-5$ um long; dengan 2-3 embel-embel apical (jarang 1), keluar dari ujung sel apical dengan panjang 10-20 $\mu \mathrm{m}$ long, tidak sama panjang; terdapat embel-embel di sel basal, jarang dua, dengan panjang 4-7 $\mu \mathrm{m}$. 


\section{Karakterisasi Patogen secara Molekuler}

Identifikasi molekuler ini berdasarkan analisis genetika secara parsial pada lokus Internal Transcribed Spacer (ITS) ribosomal DNA cendawan. Purifikasi PCR product dilakukan dengan $P E G$ precipitation method (Hiraishi et al., 1995) dan dilanjutkan dengan siklus sekuensing. Hasil amplifikasi ITS1/ITS4 universal, keempat isolat yang diujikan memiliki pita DNA berkisar antara 525 hingga 550 basepare (bp) dalam marker penanda 1 kilobasepare (Kbp) sebagai pembanding.

Hasil yang diperoleh untuk 4 isolat uji yaitu yaitu Pseudopestalotiopsis coccos strain CBS 272,29 dengan homolog mencapai 99,62\%, Pseudopestalotiopsis simitheae dengan homolog mencapai $99,04 \%$, yang selanjutnya kedua isolat t e r s e but dis e but s e bag a i Pseudopestalotiopsis compelex, Neopestalotiopsis cubana dan N. Elipsospora yang selanjutnya disebut sebagai Neofusicoccum compelex. Pemberian nama compelex di bekang nama genus karena umumnya ke dua jenis yang terdeteksi memiliki tingkat homolog yang mendekati. Untuk memperoleh nama jenis cendawan yang menjadi target perlu dilakukan uji PCR lebih lanjut dengan penggunaan Primer Elongation Factor ( EF) dan Beta-tubulin.

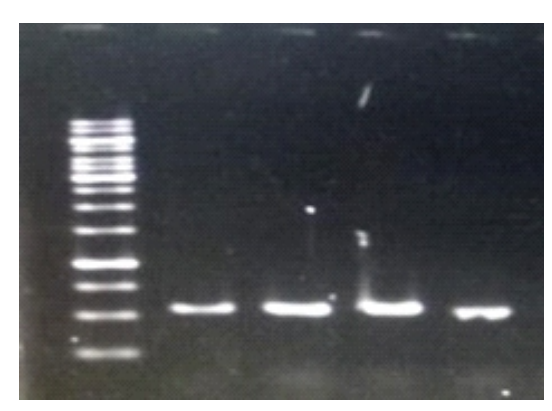

Gambar 7 Hasil amplifikasi menggunakan universal ITS1/ITS4 pada gel agarose 1,2\%, 100 volt selama 45 menit. garis 1 berisi marker 100 bp, garis ke 2 sampai 4 berisi isolat patogen gugur daun

Figure 7. Results of the amplification using universal ITS1 / ITS4 on agarose gel 1.2\%, 100 volts for 45 minutes. line 1 contains $100 \mathrm{bp}$ markers, lines 2 to 4 contain isolat of pathogen leaf fall disease

Tabel 3. Hasil Blash dengan data GenBank NCBI

Table 3. Blash result with Genebank NCBI data

\begin{tabular}{ccc}
\hline Nama di NCBI & Tingkat kekerabatan & Kedudukan \\
Name in NCBI & Correlation & Position \\
\hline Pseudopestalotiopsis coccos strain CBS 272,29 & $99,62 \%$ & Material type \\
Pseudopestalotiopsis simitheae MFLUC 12 01201 & $99,04 \%$ & Material type \\
Neopestalotiopsis cubana strain CBS 600,96 & $99,26 \%$ & Material type \\
Neopestalotiopsis elipsospora strain CBS115113 & $99,26 \%$ & Material type \\
\hline
\end{tabular}

Keterangan (Remaks): NJ (Nighbor-Joining); ML (Maximum likelyhood)

\section{Postulat Koch}

Berdasarkan hasil terlihat gejala muncul berupa bercak kemudian bagian tersebut menjadi nekrosis yang tidak beraturan dengan pinggiran berwarna coklat, pada gejala yang A dan B, bercak menjadi melebar sehingga membentuk bulatan dengan bagian tengah mengalami kematian jaringan, sehingga bagian jaringan yang mati terlihat jelas. Hasil Postukat Koch ini terlihat kedua gejala yang muncul sama seperti gejala alami di lapangan. 

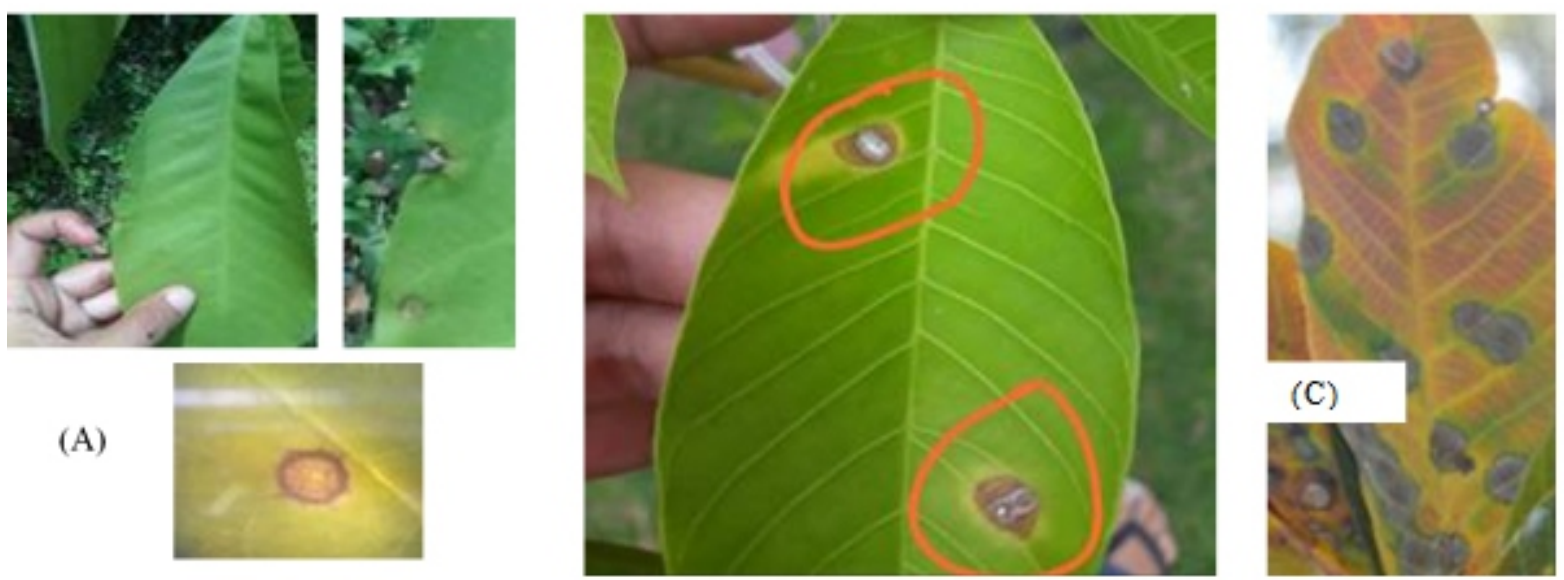

(B)

Gambar 8. Gejala hasil inokulasi spora Pestalotiopsis sp (A, B) dan Pestalotiopsis secara alami di lapang $(\mathrm{C})$.

Figure 8. Symptoms of inoculation of spores Pestalotiopsis $s p(A, B)$ and Pestalotiopsis sp naturally in the field (C).

Diagnosis penyakit tumbuhan ada yang mudah, karena gejalanya khas, tetapi lebih banyak yang sulit ditentukan penyebabnya karena gejalanya banyak yang mirip satu sama lain. Apalagi penyebabnya kebanyakan adalah adanya organisme yang sukar dilihat dengan mata telanjang (Campbell et al., 2003). Robert Koch, pengemuka Postulat Koch memberikan rumusan berupa sejumlah kondisi yang harus dipenuhi sebelum salah satu faktor biotik (organisme) dianggap sebagai penyebab penyakit. Dalam Postulat Koch disebutkan, untuk menetapkan suatu organisme sebagai penyebab penyakit, maka organisme tersebut harus memenuhi sejumlah syarat. Pertama, organisme selalu berasosiasi dengan inang dalam semua kejadian penyakit. Kedua, organisme (patogen) dapat diisolasi dan dikulturkan menjadi biakan murni. Ketiga, hasil isolasi saat diinokulasikan pada tanman sehat akan menghasilkan gejala penyakit yang sama dengan tanaman yang telah terkena penyakit. Keempat, dari tanaman yang telah diinokulasi didapatkan hasil isolasi yang sama dengan hasil isolasi yang pertama (Dwijoseputro, 1994).

\section{KESIMPULAN}

Penyakit gugur daun baru pada tanaman karet telah mengakibatkan pengguran daun secara sporadis hingga 7590\%, yang mengakibatkan kanopi menjadi tipis, penyakit ini menyerang semua klon dan tidak ada klon yang resisten terhadap penyakit ini. Juga penyakit menyerang pada semua umur tanaman. Hasil karakterisasasi secara morfologi dan molekler menunjukkan bahwa pathogen gugur daun adalah Pestalotiopsissp.

\section{DAFTAR PUSTAKA}

Agrios, G.N. (2005). Plant Pathology. Ed-5. San Diego, US: Elsevier Academic Press.

Barnett, H.L., \& Hunter, B.B. (1999). Illustrated Genera of Imperfect Fungi. Ed ke-2. Minnesota, US: APS Press

Campbell, N.A,. Reece, J.B., \& Mitchell, L.G. (2003). Biologi Edisi Kelima Jilid 2. Jakarta, Indonesia: Erlangga. 
Douira, K., Karima, S., Jihane, T., Mohamed, C., \& Amina Q.T. (2014). Study of Pestalotiopsis palmarum Pathogenicity on Washingtonia robusta (Mexican Palm). Int. J. Pure app. Biosci., 2(6), 138-145.

Dwijoseputro, S. (1994). Mikrobiologi Pangan. Jakarta, Indonesia: Gramedia Pustaka Utama.

Escalante, M., Damas D., Márquez D., Gelvez W., Chaco'n H., Diaz A., \& Moreno, B. (2010). Diagnóstico y evaluacio'n de Pestalotiopsis e insectos inductores,en plantaciones de palma aceitera al sur del lago de Maracaibo. Venezuela Bioagro, 22, 211-216.

Febbiyanti, T.R., Fairuza, Z., Kusdiana, A.P., \& Herlinawati, E. (2018). The outbreak of Fusicoccum leaf disease in Indonesia and the potential yield loss. International Plant Protection Workshop. Palembang, Indonesia

Febbiyanti, T.R. (2019). Severe Outbreak of Pestalotiopsis Leaf Disease in South Sumatra : The Need for International Cooperation. The $M R B-I R R D B$ Workshop. Mahkota Hotel. Melaka, Malaysia.

Hopkins, K.E., \& McQuilken, M.P. (2000). Characteristics of Pestalotiopsis associated with hardy ornamental plants in the UK. Eur J Plant Pathol, 106, 77-85

Mahamooth, T., Tan, S.S., Raimathy, K., Goh, Y.K., \& Patric. (2017). Oil Palm Pestalotiopsis Leaf Spot Disease Endemic in Southeast Asia is Attributed to a Complex of Synergisms between Microbial Pathogens and Not by a Singular Pathogen. International Oil Falm Confrence. Cartagena de Indias Convention Center. Colombia
Maharachchikumbura, S.S.N., Larignon, P., Hyde, K., Al-sadi, A.M., \& Liu, Z.Y. (2016). Characterization of neopestalotiopsis, pestalotiopsis and truncatella. species associated with grapevine trunk diseases in France. Phytopathologia Mediterranea, 55(3), $380-390$. D o i : 10.14601/Phytopathol_Mediterr18298.

Malik, A.A.Z., Atan, S., Mahyudin, M., Noran, A.S., \& Maiden, N.A. (2019). Leaf fall disease caused by Pestalotiopsis sp. The MRB-IRRDB Workshop. Mahkota Hotel, Melaka, Malaysia.

Malik, A.A.Z. (2018). Leaf spot disease of Hevea caused by Pestalotia sp ppt. International Plant Protection Workshop on Integrated Disease Management In Rubber Plantation, Aryaduta Hotel, Palembang, Indonesia.

Martoredjo, T. (1989). Pengantar Ilmu Penyakit Tumbuhan Bagian dariPerlindungan Tanaman. Yogyakarta, Indonesia: Andi Offset

Mehrota, R.S., \& Aggarwal, A. (2003). Plant Pathology. New Delhi, India: Tata McGraw-Hill Publishing Company Limited.

Metz, A., Haddad, A., Worapong, J., Long, D.M., Ford, E.J., Hess, W.H., \& Strobel, G.A. (2000). Induction of the sexual stage of Pestalotiopsis microspora, a taxol-producing fungus. Microbiology, 146(8), 2079-89. Doi: 10.1099/00221287-146-8-2079

Mustika, I., \& Rahmat, A.S. (1993). Efikasi beberapa macam produk cengkeh dan tanaman lain terhadap nematoda lada. Prosiding Seminar HasilPenelitian dalam Rangka Pemanfaatan Pestisida. Bogor, Indonesia. 
Ngobisa, N.A.I.C., Ndongo, P.A.O., Doungous, O., Godswill, N.N.S.W.N., \& Ehabe, E.E. (2017). Characterization of Pestalotiopsis microspora, Causal Agent of Leaf Blight on Rubber (Hevea brasiliensis) in Cameroon. Proceedings of International Rubber Conference 2017. Jakarta, Indnesia.

Pirone, P.P. (1978). Diseases and pests of ornamental plants. New York, US: Wiley Interscience.

Situmorang, A., \& Budiman. A.F.S. (1990). Timbunya epidemi penyakit gugur daun Colletotrichum di perkebunan karet dan usaha pengendaliannya. Lokakarya Nasional Pemuliaan Tanaman Karet 1990. Pontianak, Indonesia.
Soepadmo. (1980). Suatu pemikiran tentang pengendalian penyakit daun pada tanaman karet. Menara Perkebunan. 48(5), 147-154

Suada, I.K., \& Sunit, N.W. (2014). isolasi dan identifikasi patogen getah kuning manggismelalui pendekatan postulat kochdan analisis secara molekuler. Jurnal HPT Tropika, 14(2), 142 -151. 